\title{
Essays
}

\section{Chief Isaac Oluwole Delano: The Man, His Time, and His Significance}

\author{
Toyin Falola \\ University of Texas at Austin \\ toyinfalola@austin.utexas.edu
}

Chief Isaac Oluwole Delano was a Nigerian expert in the Yoruba language and culture who was born in the Ifo District of the Abeokuta Province on the $4^{\text {th }}$ of November, $1904 .^{2}$ He was born to the family of Chief Edmund Delano and Rebecca Delano (both Egba indigenes). His educational exploits started from Holy Trinity Primary School situated at Okenla Christian Village in Ifo. From there, he was moved to Lagos Grammar School under the tutelage of an Anglican Bishop, Solomon Odutola, and his principal, Reverend E. J. Evans. However, situations necessitated his transfer to Kings College in 1921 where he met with his lifetime friends and college mates; Sir Adetokunbo Ademola, Justice N.O.A. Morgan as well as Dr. Oladele Ajose, to mention a few.

Having passed his Senior Cambridge Examinations in 1923, Chief Delano proceeded to successfully write his Senior Clerical Examination in 1924, which propelled him to join the civil service in the same year. However, a severe injury sustained from an accident in 1947 led to his invalidation from the civil service. Worthy of note is the fact that he never blended into the civil service bureaucracy, as his principles and religious faith were constantly tested by various practices within the service. His dream to become more lettered was not going to succeed by his involvement with the civil service alone, and he was not positioned in those days to enjoy the privilege of travelling overseas to further his education. He had studied shorthand, and his love for writing by default made him aspire to a lifetime of authoring. While belonging to a

1 Originally published as Chapter 1 in Toyin Falola. Cultural Modernity in a Colonized World: The Writings of Chief Isaac Oluwole Delanọ. Austin: Pan-African University Press, 2020.

2 More pieces of information on his life and work can be found in Appendices 1-3 in Toyin Falola. Cultural Modernity in a Colonized World: The Writings of Chief Isaac Oluwole Delanọ. Austin: Pan-African University Press, 2020. 
number of literary societies, he tried his hand at writing newspaper articles which were generally well-received by the public. He was able to maintain a following from there, and this fueled his desire to write more works for public consumption; he was determined to make his mark in the field of writing. His first work as an author was published in 1937 under the title The Soul of Nigeria. This feat gave him his first taste at writing as an occupation, and the happiness that followed suit spurred him to achieve more. Isaac Delano believed that the first one was always going to be the hardest. His first published work had landed him on top of the world, and he was determined not to rest on his oars.

Essentially, the book sheds light on the various practices that prevailed in the southwestern region of Nigeria. It discusses some aspects of life that were ubiquitous in the boisterous and bubbling cities that dotted the Yoruba landscape. Delano lends input of his views concerning the prevalence of witchcraft, native religion, and the activities of various cultural institutions in the region. It also delved into the mannerisms of the communal as they relate to the activities of tricksters, which is a known vice in any developing city. While the book was expository enough, Delano initially doubted his own work; believing that his writing was vain. Just like a man that strives for excellence, Delano embarked on a self-assessment of his first work and felt perturbed by some slight flaws. However, his growing audience never felt such. The Soul of Nigeria was applauded for the richness and quality of the content. Another noteworthy fact is that Isaac Delano's first book also received accolades from C.K Meek, a British anthropologist who had carved out a niche for writing about various people in Nigeria. Meek allegedly affirmed the contents and style with which The Soul of Nigeria was written as exhibiting quality, creativity and strict attention to detail. At a time when Africans were still yet to be involved in writing expository essays, the commendations by Meek, if they were anything to go by, represented an objective assessment.

Despite the wide acceptance his first book gathered, it was going to take another six years before he successfully published another book. However, a great opportunity came his way when the Lutterworth Press created a popular series which was designed to motivate Africans to take to writing. The series, titled Africa's Own Library, was established for documenting the exploits of great icons and personalities in Africa with a view to assisting educated Africans so as to give them a platform to showcase their knowledge and researching prowess. With this respite coming his way, he published three books in quick succession, lending credence to his talent, hard work and ability. Among the three books, the first one took the form of a pseudo-biography of an icon of Yoruba descent, Reverend Canon Josiah Ransome-Kuti. This work detailed aspects of Josiah Ransome-Kuti's life from his birth to his death. The major 
aspects documented in this book revolved around Josiah Ransome-Kuti's exploits as a songster and minister of God as well as an administrator for the British colonial government. It would not have been possible for Delano to get so many facts about the life of Josiah, but as fate would have it, the late Josiah Ransome-Kuti was transferred to Ifo to head the District Churches there. Ordinarily, Josiah's congregation and fellow worshippers objected to his transfer, but as documented history revealed, the Ifo District Churches were experiencing serious issues with the indigenes, and they needed the experience and effectiveness of a seasoned minister of God to handle it. Since Isaac Delano was also born into a Christian family, it was quite normal to expect the two sets of parties to meet sooner rather than later. This book was titled The Singing Minister, a title that illustrates the person of the character in view.

In the same year, Delano published another work, An African Look at Marriage, which was written with the conviction that it would be helpful in the growth of Christianity in Nigeria. Delano was quick to point at his naivety with respect to being qualified for what he was writing about, since there is a full Christian Ordinance that tackles matrimonial issues in Nigeria. The major note in this book was focused on bringing to the fore the marriage system that existed in the traditional and cultural realm of Nigerian societies, and the subsequent disparity with the imported marriage system that was introduced as a strong tenet of Christianity. As reported in the book, Delano affirmed meeting various church priests and bishops in the church missions in Nigeria on the issue of contrasting marriage systems in Nigeria, and how the church was determined to relegate the African marriage system to the background to favor the imported European style of marriage. Furthermore, he claimed that most of the church leadership mentioned had cause to support the views he discussed in the book. The concluding part of the introduction took the form of advice, as Delano hoped to convince the church authority in Nigeria and in England to understand that the marriage system imported with Christianity could weaken the church in Nigeria, making all the labor put into it become vain. The above was clearly discussed in the second chapter of the book, as Delano went on to emphasize that the church had nothing to fear in the marriage system of Nigeria. The reason for Delano's extensive advises to the church authority hinged on the premise that people might get discouraged by this and leave the church.

Delano was also quick to point out in this book the growing acceptance of monogamy as a standard of Christian marriage. He explained that monogamy had become something to be accepted as part of civilization while, polygamy was becoming profiled as an archaic marriage system. He went ahead to deliver an exposé on how the church authority instituted strict penalties on church members who fall from the standard of monogamy. As if this was not 
enough, the church restricted certain privileges such as baptism from children born out of wedlock, while older members were barred from holding official positions in the church. This, as Delano pointed out, led to church members hiding their private lives from the church. While the church upheld monogamy as the standard of marriage, the onus of exercising discipline was a burden for the individual pastors in charge of such churches.

Isaac Delano succeeded in highlighting clearly reasons for discrepancies in the marriage system that exists in African traditions and the imported monogamous marriage system. He explained in succinct terms regarding the purpose of marriage, as he understood it, by employing three criteria: love, companionship and sexual desire. He was able to clearly outline why Europeans would favor monogamy, as their own purpose for marriage revolved around love and companionship. He asserted that Africans had yet to start marrying for love; rather, they engaged in marriage for procreation, hence the desire to have more than one wife. He followed this by giving detailed explanations on the concept of African marriage and its accompanying elements, such as dowry payment. This, he advised the church to inculcate into the monogamy setting that the church authority promoted.

Delano's third published book in 1944, Notes and Comments from Nigeria, was dedicated to the Nigerian Youth Movement. This was his second contribution to the Lutterworth press project in Africa earlier mentioned. The contents of the work reveal a compendium that spanned a period of ten painstaking years, spurred by Delano's consciousness of belonging to a race of people who had made a lot of mistakes and misdeeds in the past. He further disclosed that despite these flaws, he was proud to be a Nigerian. As part of his information-gathering process, he had cause to study in different places and at different times, while also putting his ears to the ground to get the impressions of people with respect to the subject matter. Notes and Comments from Nigeria contained a first-person view about various practices in the landscape of Nigeria. It talked about the cultural heritage of some tribes as well as the religious alignments that demarcate the country into a predominantly Muslim North and a mixed, albeit liberal multi-religious South. It clearly outlined the cultural parallel that exists in the country of Nigeria. Of particular note is the practice of or early marriage between a boy and a girl in the North, a custom that is in total dissonance with the custom of the Yoruba people in the South. Bordering these two customs is the boy bride custom of the Ilorin, a practice that seems more like a hybrid of the Yoruba and Hausa marriage custom. It involved a boy that was not yet a teenager dressed as a bride, and accompanied by the bride's friends to the future husband's house. In the book, Delano also gave his view on the future of the local church in Nigeria, with particular reference to the Sacred Order of the Cherubim and Seraphim, one 
of the earliest local churches that infused the traditional essence of African spirituality into Christianity.

In all, Delano brought together various perspectives of looking at Nigeria. His travels took him to Kano, Zaria, Ilorin, and Ibadan, to mention a few. His experiences are summed up into a narrative about Nigeria that are fact and true to a high degree, conveying what he gathered in his years of travelling and meeting various kinds of people. Notes and Comments from Nigeria comprise of Delano's thoughts about people and places. He was quick to place a caveat that discrepancies may exist between how he narrated his thoughts and how they are in reality. However, he ascribed that to a methodical manner of articulation that is based on providing information from observations and intuition. His passing chapter titled "The Nigerian Youth Movement" was a conscious effort to ignite the political consciousness of the youth.

His fourth book publication, One Church for Nigeria, which was his third contribution to the Lutterworth African book project in 1944, established him as a highly rated author. It was considered as a daring effort of a young man who took his religion seriously. The book contained various criticisms of the activities in the Nigeria church, as well as the inherent weaknesses he saw. $\mathrm{He}$ made sure to highlight in his own little knowledge what he believed was necessary for the country to have a united church denomination that will survive against the ills of the wicked environment in Africa. This was a text that was applauded by various church leaders with respect to the advice that was contained therein. Delano asserted in One Church for Nigeria that he had waited patiently for some church leaders who he felt were better positioned than him to write against the perceived wrongs in the church. Having lost patience by not seeing any church leader doing this, he thought that it was his responsibility given by God to make these wrongs public knowledge. He believed that while a lot of individuals had knowledge of these wrongs, they had refused to face the situation squarely. He was quick to also place a caveat to all that his opinions should not be taken en bloc, but that they should also not embark on castigating him for bringing these issues to the fore. He asserted that he had been in mediation and careful observation of these issues for a period of ten years; hence the opinions generated are truths that he was not ashamed to point out for the growth of the Christianity in Africa.

Delano continued to aspire for more education, and in 1952 secured a scholarship sponsored by the British Council to further his studies at the School of Oriental and African Studies located within the University of London. It was here that Oluwole Delano met with Professor Callaghan, with whom he discussed the possibility of him publishing an English-to-Yoruba dictionary. In order for this to be possible, Callaghan advised Delano to enroll for a specialized study in order for a standard dictionary to be produced. 
This saw to his relationship with Professor Firth, the then Head of Linguistics Department where he studied Principles and Modern Linguistics methods. There were little known Yoruba translations of English books as at this time, but this did not deter Isaac from trying even when it led to extra cost for him. After all, his belief was that the first was always going to be the hardest. Having mastered the art of English writing, it was important for Isaac Delano to try his creativity in his mother tongue, Yoruba.

In 1953, Delano published İran Ộrun ("Glimpses of Heaven”), a book intended to be used as a guide for teaching children in the church. Written allegorically in a similar pattern to the popular book The Pilgrim's Progress, it discussed biblical morals taken from the Bible that are to serve as doctrinal content for the Christian child. The essence of this book was to inculcate the gospel message into the Christian child at a very tender age in a manner that would be understandable and clear for growing children. Being born to a Christian family really helped Delano in the course of writing İran Ọrun, since he was opportune to be a part of the growth of Christianity at a young age and understood how important it was for the Christian child to be indoctrinated early. It should, however, be noted that before writing his first Yoruba book, Delano had in 1934 embarked on translating the popular fiction Robinson Crusoe into the Yoruba language as part of the requirement in a literary competition. He ended up with the second prize, and this spurred him to engage in literary works in his mother tongue.

Prior to writing Atúmọ È dè Yorùbá, Isaac Delano, while in London to further his education, successfully completed his book Aiyé D’Aiyé Òinbó, which can be translated into English to mean "the world had become a white man's world". The book depicts the cultural clash between the introduction of Western law and civilization against the native laws and customs in Nigeria. Published by Oxford University Press in 1954, the book was written in Yoruba, showcasing Delano's mastery and articulateness with respect to lettering his mother tongue; the Yoruba Language. In the preface of this book, despite it being written in Yoruba, Delano embarked on appreciating his growing followers, deliberately calling on both his indigenous as well as non-indigenous followers. The opening chapter of Aiyé D'Aiyé Òyinbó sheds light on the travails of a polygamy family. In the main, this factional novel looked into the socio-political changes brought by colonization, in Nigeria. Although he mentioned the dangers and petty dramas that often occur in polygamous homes, this was in passing and the focus was not essentially on the topic of marriage traditions, as regard monogamy or polygamy. The picture of this presented in the novel was to show the typical traditional African family setting that existed before the adoption of Western family structure under the Christian marriage ordinance. Also featuring in this regard is the theme of marriage 
traditions and the overbearing involvement of parents in the marriage of their children. The changes noted in the novel picture the reconfiguration of the political landscape of Nigeria, using the fictional Ojusango as a case study. In these changes as shown in the novel is the incapacitation and helplessness of traditional authority in the emergent society; the introduction of new policies that criminalized some traditional practices like slavery, slave trade and pawn system; the emergence of new political elites/actors; the role of education and literacy in the evolving milieu and revolution in the transportation sector. In all, the main attention of Delano in this work was drawn to the dominance of modern political structure in the colony and how the traditional authorities managed to navigate their ways through the hurdles. It was around this central theme that other changes were explored in a captivating manner. This way, book talked about the substitution of archaic models for new models imported into Nigeria. A cursory look at this will indicate that true to the title of the book, the world of African was beginning to become transformed into the white man's way.

Bearing this in mind with the need to continue to preserve the Yoruba civilization and its identity, Delano completed fundamental studies that supported the art of translation, and this led to him successfully writing Atúmọ Édè Yorùbá and A Short Book of Yoruba Grammar and Dictionary. This was going to be the first known Yoruba dictionary which contained the translation of big Yoruba words to smaller and easy to understand content, also indicating implicit details like the part of speech, figure of speech etc., the Atúmọ Ėdè Yorùbá was widely acclaimed as the first indigenous West African language dictionary. It was published by Oxford University Press in 1960. In the same year that he published Atúmọ Èdè Yorùbá, he also published Àgbékalè Ợọ Yorùbá, which is a compendium of expressions and idioms usage in the Yoruba language, bearing in mind the differences in tonal delivery of words with the same spelling that have different meanings. This is a spectacular attribute of the Yoruba language. It also contained proverbs and their proper usages, since proverbs form a significant part of the Yoruba language. In order to emphasize the import of proverbs to the Yoruba language, Delano wrote a book that was intended for students preparing for the Yoruba language in GCE. The book, Òwe L'Eșin O'rọ (translated as "proverb is the horse on which discussion is saddled"), contained a list of 500 Yoruba proverbs and their usage as they relate to advising, reproach, and warning. The proverbs are also translated to accord the reader a perfect understanding. Other notable works by Delano that showcased his love and mastery for the Yoruba language include İrántí Àñààní (Important Remembrances), which discussed the short history of important towns in Nigeria such as Lagos, Abeokuta and Oyo. He also wrote multilingual books such as Conversation in English and Yoruba, 
which gave some 150 conversational situations in Yoruba and their corresponding situational usages in English. This was published in 1963. Other notable works by the late Isaac Oluwole Delano include The Historical Events of Nigeria (containing a chronicle of the historical events in Nigeria from 1460 to 1964), A Modern Dictionary of Yoruba Usage (which highlighted the usage of Yoruba words, expressions and sentences with articles on special words, customs and traditions of the Yoruba people), as well as short biographies of Oba Akinyele and Sir Francis Ibiam, the latter withdrawn from press by the Oxford University Press due to the emergence of the Nigerian Civil War.

The Late Chief (Dr.) Isaac Oluwole Delano also contributed immensely to the growth of Yoruba studies in tertiary institutions in Nigeria. In 1963, he was invited to the University of Nigeria, Nsukka (UNN), to assist in developing the institution's language and linguistics department (with special reference to Yoruba), where his work resulted in him being loved and revered by students and staff alike. His stay at UNN afforded him the responsibility of mentoring and advising the Yoruba community in the institution. However, his time in Nsukka was cut short as a result of the Nigerian Civil War. Not resting on his laurels, he contacted the administration of the University of Ife, where Professor Hezekiah Oluwasanmi welcomed him by offering him a job as a lecturer at the Institute of African Studies. This would later accord his longtime admirer, Professor Adeagbo Akinjogbin, who in 1954 had written a letter to him for guidance on his historical projects, particularly in regard to insights into some cultural issues revolving round obaship system in Yorubaland. Apparently, the letter was written to Delano in recognition of his intellectual relevance at the time Akinjogbin was just starting his career as a young scholar. The two later developed a good working relationship at the Institute of African Studies of the University where they both served.

Suffice it to say that his time in Ife happened to be the most appreciated, as the authorities of the institution honored him with the honor of Doctor of Letters (D.Litt.) in the presence of icons such as Chief Obafemi Awolowo, Chief Akintola Williams, Justice Abina and Ola Rotimi.

\section{Isaac O. Delano on Values and Morality}

Society and evolution of man in it is sustained through the coinage and observance of certain values and morality rooted firmly in the traditions passed down from previous generations. The values bear the various levels of social stratifications in the society, the norms guiding the relationship among its members, the status of each member and their limitations. It is in observation of these values that the concepts of morality and immorality are conceived and known by members of the group. This is the core of every civilization, as 
it portends the agency of cultural incubation, vaccination and inoculation. ${ }^{3}$ As such, Delano could not but agree with the generic notion of family as the basis of not only a community, but of the entire cultural group. According to him, either we choose to see the concept of family from the Western or African view; it is the elementary unit from where the society could be understood. If at any time, the values and morals responsible for the survival of a culture are seen to be dwindling, check the family realities. As an undisputed cultural icon, Chief Delano-regardless of his unapologetic romance with Western civilization-was an embodiment of the preservation of African culture through his various activities. ${ }^{4}$

With this understanding, the idea of value and morality in Delano's works are substantially illustrated in the hierarchical structure of the African family and how this helped to sustain African communalism, particularly among the Yoruba people. It is in this light that his ideas of values and morality are summed up under the mechanism of family; in the sense of African conception and African communalism. Delano so much believed in the doctrine of African communalism that in 1974, when he was called upon by the University of Ife (now Obafemi Awolowo University) to give a convocation speech, he could not think of any other appropriate lecture than an insightful piece that related his communal convictions. Fearing the consequences of rising inequality in Nigeria, Delano reminded his audience what could have been the perpetual fundamental ethics of doing business: "The first function of industry is service to the community," ${ }^{5}$ he noted. In the age when rivalry between the old and the young is depriving the society of much-needed progress, he admonished his audience-the university community, government representatives and the general public - to note that cooperation rather than competition between both generations could achieve the dreams and purpose of their differences. Actions such as students carrying placards; school management's proclivity to clampdown on them; government enforcing its will by means of

3 On the flip side, this often leads to prejudice and stereotype of others outside this cultural group. Cf. Henri Tajfel, "Social Psychology of Intergroup Relations," Annual Review Psychol., Vol. 33, Annual Reviews Inc., 1982.

4 Cf. Akinwumni Isola, "Making Culture Memorable: The Literary Contributions of Isaac Oluwole Delano," Lecture Delivered at the Isaac Oluwole Delano Inaugural Memorial Lecture, Muson Centre, December 20, 2004. The lecture is reproduced as Appendix 4 in Toyin Falọla. Cultural Modernity in a Colonized World: The Writings of Chief Isaac Oluwole Delano. Austin: Pan-African University Press, 2020.

5 Chief Isaac O. Delano, "Address to the Special Convocation of the University of Ife for Conferment of Honorary Doctorate Degree on him and Dr. T. O. Elias," October 19, 1974, 3. (The entire lecture is reproduced as Appendix 5 in Toyin Falọla. Cultural Modernity in a Colonized World: The Writings of Chief Isaac Oluwole Delanọ. Austin: Pan-African University Press, 2020.) 
force-all in a bid to convince the other of their own power, relevance and idea of a better society, in lieu of dialogue and compromises, will only lead to one ultimate situation and that is chaos.

By the time Chief Delano delivered this speech, he was already a man of grace living his $70^{\text {th }}$ year on earth. So, he was speaking with the experience and audacity of a man that had journeyed in the kaleidoscopic path of life confronted with many actions and consequences. The failure of forming a common union for the Nigerian church in its first attempt, twenty years after he wrote about the necessity for such and the things to be fixed before this, remains memorable in this discussion. This time, with a lucid anecdotal piece, he described the prevailing perception of the young as they regarded the old and vice versa, and concluded that:

The old must place their wisdom and experience at the service of the young yet allow vitality, energy and enthusiasm of youth freedom and scope; the young must respect and honour the achievements and practical sense of their elders and place their physical strength and vigor at the service of the community if it is to continue. ${ }^{6}$

After all, the old ones were once the young and the young ones would soon grow to become old, taking up the responsibilities of elders. Then, the only way in which the relationship between these two generations could be beneficial to the society, as illustrated in Delano's works, is when the individual plays his/her role within the hierarchical structure of the society, which is depicted in the African family structure. In this structure, the father is the head of the family. His orders are final because it is believed that he knows best, given his experience and exposure. The father himself is subjected to the authority of the eldest man in the compound, who he revers and obeys. Although, traditionally, a child cannot challenge or offer suggestions as to the direction they nod at, Delano's pragmatic inclination becomes a bridge in this strict rule in the face of modernization. At least, if this could not be proven by deducting every part of his works that speak to this, the extracted text given above lays credible credence to this. Contrary to the bygone days, considering the changing trend of events around the world and the swift pace at which these changes are emerging, Delano was not under the illusion that age is equivalent to knowledge. In fact, in one of his writings that speaks to this, he showed that whereas the bygone days were driven more by wisdom, the contemporary world is driven more by the accumulation of knowledge.

6 Chief Isaac O. Delano, Address to the Special Convocation, 4. 
While the experience and age of elders in those days accumulated into the wisdom with which they controlled the society without questioning; the vigor, vitality, energy and enthusiasm of the youths in the contemporary world place the continuous acquisition of knowledge at their disposal. Thus, the above assertion that the knowledge of the youths and the wisdom of the elders must be blended to produce a better society. At any rate, it is a common wise saying among the Yoruba people that: owọ omọdé ò tó pẹpe, t’àgbàlagbà ò wo kèrègbè-the same way a child's hand cannot reach the ceiling, that of the elder cannot enter the calabash. This way, adjusting this tradition to the signs of the times, the child can offer suggestions to the elder on how to go about things, but in a respectful manner. Respect is at the core of morality in Yorubaland. The youngest wife respects the first wife and others before her; all of them respect their husband and revere every member of their husband's family, even to a fault. In addition to this, the youngest wife is expected to honor every child she meets in her husband's house. One of the ways she does this is by tactically avoiding to call them by their names, but through a carefully coined name she might choose to call them-e.g., Awelewa, Awero, Oloye, Balogun and the likes. When they feel offended by anyone, including these family members, their right is to report such to an elderly fellow who adjudicates on the matter in a peaceful manner. Immorality in this sense is when one takes the law into his/her own hands arbitrarily.

All these courtesies are given back to the youngest wife when a new wife comes in. Even if she finally becomes the last wife, she is still accorded her respect. In this same manner, peace reigned relatively. This, however, as Delano noted, is not without some human weaknesses, as troubles do ensue in such a polygamous setting. Meanwhile, the reciprocity of respect and service in this society could be seen in the relationship between the younger children and the older ones. For instance, the younger ones would help the older ones in carrying their loads when working together; in turn, the older ones would defend their younger ones against any external threats. Also, having run different errands for the elders during the day, the children are delighted with stories, tales and riddles in the evening after taking their meals. Therein they learn proverbs, metaphors, idioms and lot more, which impart wisdom in them together with the lessons they've absorbed through various informal learning opportunities during the day. This way, not only did everyone in the society know his/her limit and play by their status, education was conducted in a subtle manner that impacts the bearing of the community.

Delano related to us the two forms of punishment that were developed to check the excesses of children. One is the punitive and the other, preventive. The former comes after the offence had been committed, while the latter adopts fear. In the former, the erring child would be spanked, as the Yoruba 
believe that "Whip is the god of children." In the latter, children are told not to do this or that because of some cancerous repercussions. The latter embodies the fears of the society, either to the safety of the child or the entire society. For instance, a child is told not to draw a line on the ground because if s/ he does, his/her mother would die. Delano noted that given the love children have for their mothers, they are more likely to resist the temptation of going against this rule. For the society, the implication is that without children drawing lines, if they come across such a line on the ground they can discern more quickly if such paths were laid by an animal, like a snake, which needed to be hunted before it hurt anyone. This and many more were developed to ensure the general security of the society. As it would later be seen, Delano believed that though scientific discoveries and interpretations of things are not bad in themselves, to ensure productive human relations and survival of the human society, some sets of myths are required. Many years after this was said, historians, philosophers, sociologists and anthropologists have not ceased to authenticate this noble truth. ${ }^{7}$

At the time, all these were strictly adhered to, education was impacted to enhance the morality of the children within the value system of the culture. As such, cases of adultery, stealing, drunkenness, waywardness and the like were very rare. Children were very important to the parents, and anyone who died without a child was regarded as unfortunate. Delano illustrated the importance of this in proverbs; two of such will suffice here. Firstly, omo kò láyọyèlé, eni ọmo sin ló bímọ-children are not a cause for rejoicing in themselves; it is the man who is buried by his children who has had children. Secondly, iná kú feérú bojú, ògẹdẹ kú fọmo rẹ rọoọ̣; ijọ a bá kú, ọmọ ẹni ni yóó gbẹyin ẹni-when the fire is extinguished, the ashes cover its face; when the banana tree dies, its young shoots succeed it; when a man dies his children should succeed him. Owing to the importance attached to children, the parents ensured that they took the frontline in using their spouses. For the male, his father was responsible for finding his first wife; and for the female, both parents would go in search of a proper partner. However, in both cases, the children must have been matured as the Yoruba do not practice child marriage.

More importantly, marriages in this tradition were conducted with greater premium given to the solidarity of groups or families involved, as marriage is conceived as a social obligation to the community and not a private affair. Hence, both parents and the entire community were meant to see to it that the marriage was sustained, having conducted in-depth research before sealing

7 See, for instance, Yuval Noah Harari, Sapiens: A Brief History of Humankind, United Kingdom: Harvill Secker, 2014. 
the bond between the couples. As a form of compensation for the training of the bride to become a responsible wife and their roles in the betrothal process, dowries were shared among family members and others in the community. In essence, Delano showed that the communal bond in such marriages, predicated on the social and religious structure of the people, helped in stabilizing the society. It is not to say that couples didn't go through divorce during this period, but the grounds were tight, thereby reducing the numbers of children raised in broken homes, as it is in recent times. Accordingly, Delano informed us that:

The approved grounds for divorce are incurable disease, impotence, insanity and loss of citizenship; this last item means that, if a husband has been jailed for a disgraceful crime, the wife can use this as a ground to divorce him because he has lost his right to privileges enjoyed by the citizens of the tribe. He has become an outcast. ${ }^{8}$

Tellingly, because of the communal bond as well as the social implications of marriages, adultery-aside from the shame and punitive punishment that was attributed to it-was rare. In view of all these, Delano bemoaned how adultery has become a thing of pride among men and women, as well as drunkenness now a part of civility; thieving and bribery a pathway to survival; divorce on frivolous grounds an escape from responsibility; and insolence as a sign of modernity. In his idea of value and morality, dignity of labor resonates loudly. On several occasions and in his various writings, Chief Delano warned of the danger that the erosion of our traditional occupationfarming-portends for the society in the face of modern occupations (both white and blue-collar careers) and the economic condition of the country. Before this became a big issue at the center-stage of government rhetoric and politician's demagoguery, Delano had written about this and provided an instructive solution that if it takes the Nigerian government over 100 years to go come to its senses, it would have to go back to it. The question is: "Why can't the farmer after a day's toil sit quietly in his home, read a little history, or romance or a play or play on the piano and his kiddies and wife moving

8 Where the materials are drawn from the scanned copies of the Private Collections of Chief Isaac Delano, in the possession of his son, Chief Akinwande Delano, I do not paginate in this note and several others to avoid confusion with the original materials. The scanned copies do not always carry the same pages as in the original. See Appendix 6 of Toyin Falola. Cultural Modernity in a Colonized World: The Writings of Chief Isaac Oluwole Delanọ. Austin: Pan-African University Press, 2020 for a list of Delano's publication. 


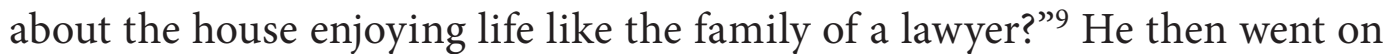
to suggest three things: "(l) make village life very attractive; (2) raise farmers' earnings by substantial government subsidy; (3) accept farmers into our society as honorable men." 10

But for the businessman to regard the community in his profit calculations, or for the politician to work his talk and to attain the general values that would promote a prosperous society, Delano believed that religion-in spite of its inadequacies found in some of its irrational accounts-holds the center stage. Like the conductor in a choir, religion, to him is the coordinator of all morals, values and the consequences of adhering or ignoring them. Therefore, religion is seen to be the producer of the nature of a society, as the conductor produces the rhythm, flow and sound of a choir;

Of the two invading religions in Nigeria it is the great "something" in Christianity which has made it one of the formative influences in the development and progress Nigerians can boast of today. I tend to see this development and progress as expression of a reality in religion and not in scientific discoveries. I am not referring to religious system as defined by rituals and constitution, but that inward development and belief which raise our moral standard and strengthen us to do what is right, just and proper.

From the above, no one could be in doubt of where the dedication and root of Chief Delano's morals and values lay during his lifetime.

\section{The Route to Cultural Truths: Factions and Fictions}

There is no other route to realizing the truth of culture and practices than time and consistent conscious education. Time, they say, heals everything; but when it comes to healing a mish-mash of rationality and irrationality in cultural practices and values, proper education is needed to sustain cultural truths. From Delano's his literary works to others, wherein he articulated his views about the Nigerian church, the veracity of this resonates loudly. One of the consistent features of these works is the increasing consciousness with which the people practiced or struggled to model Nigerian Christianity as against the imposition of the European missionaries. As the most active agents of modernization with effects on the traditional practices of Africans and their world view, the Western Christian missionaries were responsible for denunciation and alienation of African cultures. Whereas the people had

9 Chief Isaac O. Delano, Address to the Special Convocation, 6.

10 Ibid. 
agreed, although reluctantly, to the belief that all that was related to their culture and traditions were devilish, barbaric and backward, and therefore should be thrown out in favor of European civilization, with time and the increasing spread of Western education all these were demystified by the people.

The ability to read the Bible, which came along with their literary skills; close interaction with Western culture and civilization; as well as growing nationalist dispositions of the people aided by the cultural evangelization of the likes of Delano-all transcending the time and space in which the people lived-culminated into the deconstruction of facts from the fictions of their cultural practices. It should, however, be noted that this consciousness was not only premised on the Christian faith, it was also felt on their long-held traditions they considered irrelevant to their socioeconomic and political milieu. To practice good Christianity, the people were told the totality of their being in the traditional sense was the reincarnation of the biblical devil, which they needed to be cleansed of. This devilish act, they were told, remained evident in all aspects of their lives since the foundation of their political culture and its structures, which dictates all other aspects of life, were built on the wings of Lucipher. They were reminded that the dreadful Ogboni cult, the most powerful political structure in the state, for instance, was engaged in all sorts of rituals including making human sacrifices; the selection and installation of an Oba-elect required consultation with the gods that took blood and other items considered backward to civilization; and so on, continuing in this pattern.

Traditional medicines were also considered satanic because the chanting of incantations was also involved. Furthermore, organizing wedding or naming ceremonies in the traditional form, they were told, negates their new belief because in the two cases, a fortune teller and an herbalist must be consulted to be informed about the road that lays ahead as well as the necessary sacrifices that needed to be made to the annex the support of the "impotent" gods. ${ }^{11}$ Having deprived themselves of the traditions associated with marriage and marrying strictly by the European way, which was the Christian way, they were told to relinquish the polygamous family structure. As this became the case, many, like Balogun Igbien in L'Ớ jọ́ Ojọ̣ Un, made efforts to change their names in replication of European names that fascinated them. Some succeeded in this; others, like the Balogun, did not as his wife prevailed on him. Delano further informed us that some would even go as far as not eating indigenous meals or wearing native clothing styles any longer. The indoctrination had told them that the more they become Western in their approach to life, the more they become Christ-like because Jesus is white.

11 See all these as skillfully drafted into Delano’s discourse in L'Ọ́ jọ́ Ojọ̣ Un, 123. 
Unlike his discussion in Aiyé D'Aiyé Òyinbó, Delano's account in L'Ớ jọ Ọjọ́ Un focused on these distortions, though presented with the validation of the author in most cases. Suggesting the relevance of time in this discussion, one could see that Delano's position on some of these issues also changed as time passed and some of the distortions were put to test. Fifake, the main character in Loó jọ Ojọ Un, showed us how time and circumstance led her and her father-the Balogun of Igbein, who would have nothing to do with traditions and insisted her wedding must be conducted strictly in the Christian wayback to the traditions they had once despised.

Sọlápé, șùgbọ́n ojú kòi là si nígbàtí bàbá rẹ ń gbé mi ní iyàwó. Bàbá mi a má a yangàn bí aláṣejù àti ẹni tí tirẹ yoyé nídií isin İgbàgbọ. Ó ń șògo nínú rẹ. Bí kò sí ti ìá mi, òn náa fẹ yí orúkọ padà sí orúkọ Òyìnbó... ${ }^{12}$

Șọlápé, back then when your father got married to me, things were not the same as now. My father was very proud of Christianity, so adherent to the religion. He gloried in it. If not for my mother, he almost changed his name to the Western name.

By the time trouble beckoned, Fifake recalled the incantations she needed to chant to avert the situation; her father remembered the herbalist that was effective in saving his grandchild; the mother didn't object to this as she did her own part in the reversion to traditions, and neither did her husband, who was trained by one of the earliest European missionaries. At the same time, none of them denounced his/her Christian faith. Although they claimed this was because they had no other alternative-ișu ẹni ní mú ni tọwọ́ bọ epo, the Balogun declared - the truth is, they all reverted to tradition because it was deeply a part of them, more than the new one they were trying to immerse themselves in, and it was a fallacy to think they could successfully run away from it, one way or the other. While this could be said to have been circumstantial, other examples subsist that could be referred to as conscious deconstruction of their cultural interpretations by the missionaries, earlier accepted by the people as the gospel truth.

This was led firstly by the ex-slaves and other educated elites in the colonial state at this time. Leading the revolt on cultural prejudice, churches were established with doctrines that accommodated some of the practices the European missionaries considered as torpedoes to the Christian faith. Evident in this light was the prohibition of the people from dancing in the church and having more than one wife. Even before the establishment of these churches,

12 Ibid. 
the delusion of the former was palpable. Fifake could not stop wondering why more than ten people would gather in a place to sing and none of them would dance. Dancing and singing are integral parts of African culture. She could recall how her parents used to dance to the amazement of the children before they got converted. But her wedding day was not a day meant for wondering, it was a day of spontaneous action, letting out her real person in excitement. Even though the event was strictly conducted by the church, this could not be a solemn affair. Together with her guests, she danced and won herself a new name, Foluke. The officiating pastor at the wedding was apparently aware of this as it was not an esoteric event, yet this could not stop the church from conducting the event.

Meanwhile, as Delano became more exposed himself, he began to critique the marriage traditions and church doctrines in Nigeria. In a letter written to Rev. Melville Jones, the then Anglican Bishop of Lagos, found in one of his personal records, Delano did not hide his fascination with the conduct of service in the Cherubim and Seraphim church after he attended its program. One of his fascinations with this Christian denomination was the act of dancing and rejoicing in the church where the people showed their African-ness. Some of these new denominations established to create an "African air" in the Nigerian church even went as far as giving room for their members to marry more than one wife, because they came to realize that this was an economic and not a religious matter. At any rate, the economic condition of this period did not encourage maintaining many wives; even the ones with one wife could hardly sustain their families. Many of these doctrines, as Delano showed us, were more effective in the villages because the people could hardly juxtapose between the doctrines and deliberate derogation of their culture.

The question often asked by these churches and their members was for the churches established by the European missionaries to point at places in the Bible where it was mentioned that having more than one wife led to the condemnation of a man by God. They saw those with many wives who still maintained their relationship with God. To this people, they came to realize that their service to God and the church should be through their minds, and not the number of wives they possess. ${ }^{13}$ Also, were the ones who had multiple wives before their conversion to divorce all but one, with their children? If so, then who would be responsible for these children and women?

Aside from their other social functions, alcoholic drinks among Africans have spiritual and religious significance. They are used for propitiation and prayers. Since all that was traditional to the people was meant to be erased for modern civilization, taking these drinks was also painted as evil. Added

13 Ibid., 70 . 
to this was the missionary pursuit of racial hierarchy. As such, Africans were not meant to take alcoholic drinks because it would increase the evil in them and make the process of civilizing them more daunting. ${ }^{14}$ Hence, even when many of these alcoholic drinks were produced in Europe where the missionaries came from, with common and satisfying consumption by their white kinsmen, these drinks were meant to be limited in Nigeria. Using the Bible to support their claims, while the white missionaries preached against taking anything alcoholic, their African counterparts were more reserved about this and their take was that the Bible did not really prohibit this, but called for caution in its consumption. ${ }^{15}$ This was also to be later deconstructed, as churches later emerged that felt indifferent to this. Aside from this, even among the ones that still hold on to this old fallacy, it is not uncommon to find their members still taking these drinks comfortably.

Contrary to the marriage ceremony of Fifake and her like during her time, Christian marriages are no longer conducted without the traditional wedding, even though this might have been revised to avoid following some traditional rites. Christians take both Western medicine and local mixtures without incantation. As time has passed, with the people getting more educated and exposed, some of the condemned traditions began to gain currency. The ones that remained condemned were largely based on the personal convictions of the individual, and not because someone said it was so. African dresses, foods and names became the means of cultural nationalism. Today, Africans are looking at ways to refine and resuscitate African medicine as well as reconstruct the picture of African religion and religious practices, as the root of the blanket condemnation of African culture and the need to protect these traditions became clear to them.

\section{Delano and a Reflection on Social and Political/Colonial History in L'Ọ́jọ ọjọ́ Un}

Traditions and modernization are considered antithetical to each other. At the same time, the latter is seen as evolution from the former. Therefore, as every society started at the crude stage, they are expected to move ultimately to a refined state over time. Several inferences were made to this in Delano's works as he discussed the evolution of the Nigerian society in his works of faction, historical accounts and biographies. With the colonization of the area known today as Nigeria, the stage was set for the modernization process of the people and the society. In L'Ớ jọ Ojộ Un, which shares a very keen affinity

14 Cf. Akinwumi Isola, "Making Culture Memorable: The Literary Contributions of Isaac Oluwole Delano," 9.

15 See Delano, L’Ọj jọ́ Ojộ Un, 69. 
with his Aiyé D'Aiyé Òyinbó, the plot was based on the colonial experience of the people of Abeokuta, wherein Abule Onigbagbo featured prominently. The accounts presented in this text are not remote from the general atmosphere in Nigeria at this time. Presented in a factional manner, Delano mirrored in this work the changes that occurred with the coming of the European missionaries, the ex-slaves, and the colonial government; all of which were regarded as agents of change and transformation in the evolving milieu. The transmogrification of the society was multifaceted, as Western civilization overshadowed all elements of traditional practices and structures: from the political to the economic sphere, social to cultural province, the whole societal ambience was fixed to be renewed and the people set for many surprises.

Since the purpose of these agents of civilization, particularly the Europeans, was to demean cultures and traditions of the people considered lesser humans, in order to reinforce the import of theirs, which was considered the higher civilization, the former would not go down without a fight. Literally telling in this, as shown in the text, was the 1867 Ifole incident in Abeokuta where the traditionalists in the town invaded the homes and mission houses of the native Christians and their European lords. ${ }^{16}$ Delano, while reflecting on the incident, suggested that aside from the obvious reasons of their actions on that day, the invaders probably chose to carry out the attack on a Sunday because of the redefinition of the week days by the missionaries. Traditionally for the Yoruba people, all days are considered sacred because there is no day on which they don't make sacrifices and worship their gods. Nonetheless, none of these days were ever contemplated by the people to be work-free at this time. Meanwhile, one of the criteria for becoming a Christian convert was for the people to regard Sunday as a sacred day meant for resting. A covert-to-be at the time was told to observe the Sabbath day-Sunday-as a holy day when neither he nor his household would engage in any activity; economic or social, aside from attending church service. When Balogun Igbein heard this when he decided to join the Christian fold for its socioeconomic implications, he was irritated as he regarded Christianity as a religion of the lazy folks, although his position on this was later changed. His position changed because of the gains of conversion that outweighed the rules, but this was not so for many of his kinsmen that remained in the old tradition. They continued to tout the Christians as lazy elements.

Christianity became one of the most significant tools in reconfiguring the society; and with the aid of the colonial government, the religion became well-rooted in no time, particularly in the southern part of the colony. It was the religion of influence and power in the colonial state. As seen in the case

16 Oloye Isaac O. Delano, L’Ọ́ jọ́ Ojộ Un, London: Thomas Nelson and Sons Ltd., 24. 
of the Balogun briefly mentioned above, many converted into the religion for economic gains. This way, the missionaries produced more hypocrites among them than they did genuine converts; it was difficult for the people to understand why they should deny themselves alcoholic drinks, limit themselves to one wife, rest on the Sabbath day, do away with their deities and throw away their traditions. To overcome these rules, they considered iron-fisted, many reverted into hypocrisy as they told themselves convincingly that nobody could observe those rules sincerely. The Balogun Igbein-who was made a typical example of a Christian-covert-spent a long time deriding the religion and its leaders on several occasions, after he became a convert. Whereas he later became one of the overzealous converts who would not want to have anything to do with traditions until a dire circumstance prevailed on him, many of the converts soon reverted to their deities, as others continued hypocritically. In any case, by this time, the Christian coverts came to believe that there were three sets of people in the world: those that control the world, the ones that followed to serve them and the spectators. This was Balogun Igbein responding to the query of the Ogboni in Abeokuta: Ėdá tó wá sáyé kò pọ bí àwọn tó sin wọn wá, àwọn tó sin wọn wá, àwọn tó sin wọ́n wá kò pọ, bía àon tó wá wòran. ${ }^{17}$ The Christians in this succinct description of the time were in the category of the few, while the others were the rest of the society. So, it was a matter between the Christians and the others.

Be that as it may, this was indeed the case. The Christians, through the colonial government-controlled things in the southern part of the colony, including the educational system, modern health scheme, government and the rest, gained substantial influence. With this, they believed they owed the rest of the society the magnanimity of their soul to help educate the children of the "heathens" in the Western way, and save their souls from the brimstone. For the former, the argument was that Western education was the future, and anyone who desired that his/her child become relevant in the future of the emergent state must give them this heritage. Since this education was intertwined with Christianity-owing to the fact the missionaries were the custodians of the system at the time-the conversion of the children was non-negotiable. More importantly, with the support of the colonial government, the Christians were first class citizens among the natives. In times of contest for leadership or debate over societal issues, as seen in the case of Abule Onigbagbo, the Christians would always have their way. They had the ears of the Alake, his chiefs and the missionaries; and through all these people, they controlled the society to the envy of the ones that refused to be converted. They advised the Alake on issues of governance, the chiefs on the

17 Ibid., 116. 
path to tread and ultimately succeeded in rendering the Ogboni cult useless in state matters. Now, one could understand the culmination of the Ifole incident mentioned above. Staging that attack on a Sunday, as opined by Delano, could not have been incidental, but deliberate to desecrate the revered Sabbath day of the Christians.

The civilization brought by this epoch in Nigerian history transformed the face of the society. Tired of changing his roof every year, Balogun Igbein made efforts to join in the frenzy by changing his thatched roof to a modern one made of aluminum. The containers meant for eating were changed from calabashes and mere clay materials to ceramic. Few, if any, would go for palm wine where there were foreign drinks like beer. Although the missionaries had told them that taking any of these drinks would transform them beyond the civilization they intended for them, as they would become Mephistopheles himself, many still engaged in it. And for others who were not converted, it was a free license. This was not without its consequences. Delano made a detailed account of the menace allegedly caused by this in the whole of the southern part of the colony. What could have been more astonishing than the testimony of Bishop Johnson before the panel set-up by the British government to look into the issue of the abuse of drinks in the colony? In this account, Delano told us that the Bishop had gone to Warri in 1906 to investigate the rumor that all the pupils in the government school there were in the act of drinking alcohol. Upon getting to this place, he realized that out of 75 children between the ages of 8-16, only 15 of them had not tasted alcohol before in their life. ${ }^{18}$

The issue of social decadence related to excessive drinking of alcohol is next in emphasis to the impact of Christianity on the society in this text. Funnily, Fifake informed us that at the time her father became a staunch Christian, a visitor who was not contented with kolanut, water, food or cigarette would rather leave as he came, because her father would not serve his visitors anything alcoholic. This raises the question of when cigarettes became anti-Christ in the Nigerian Christian doctrine. Mirrors and other make-up materials were materials significant to this epoch. Even for the people in the village, the mirror became one of the essential materials needed for survival. So, when the Balogun went to the town from the village, this formed one of his priorities. Further to this, Fifake wondered if any woman in the quest to validate her fashion orientation and civility still wears a wrapper tied to the chest with another small cloth placed on her shoulder with a headgear, as she gets set to go out for events. She wondered if any man could be so decked in his traditional attire these days in preparation for a function, only to climb onto his horse

18 Ibid., 96. 
afterwards as he gets ready. All these have been replaced with new codes of dressing and modern transportation systems. For male educated folks, suits, white shirts, and trousers became their common outfit.

The horse had been replaced with vehicles; not the ones that moved on the waters as the people first thought, but on dry constructed roads. This particular one, the people of Abule Onigbagbo could believe, as they thought it to be an exaggeration: "how would a vehicle work on the road?" they asked. The vehicle they were familiar with was the one that used to take them across the water. When they eventually saw dry land vehicle, the flies had a field day. With this and the rising number of children getting Western education, the population of the villages started plummeting considerably to the worry of the people in the village. There was only one trend in this regard: people moved from school graduation to the city. Thus, less people began to engage in farming, while many took up government jobs as teachers, interpreters, clerks, railway workers, secretaries and other widening opportunities. Indeed, farming became less interesting as the new jobs created by the government became more profitable. These were the ones buying bicycles; the Mercedes Benz of the time. Living in the city with infrastructures not available in the villages, they were the envy of the ones in the village, and the cities that abhorred them were dream lands of the people in the village. Like in the villages, the ones controlling the cities were the educated folks.

The educated fellows were well-revered in the society. By 1865, they had set up a new government structure for the Egba people, under the leadership of the Alake. The idea of a central government among the Egba people was conceived and executed by the ex-slaves from Sierra-Leone who were the first set of educated elites and indigenous agents of civilization, with the support of the missionaries; Henry Townsend in the main. The government was structured after the modern model with a secretary at the center of operation. Interpreting Delano, after the emergence of a central government, these elites "placed the king and his chiefs in their befitting positions...the disparities in this structure was not because of foolishness but because they didn't have enough experience in this kind of matter." 19 This readily tells us who was in charge of governance. The king only did the sealing, the ones in possession of the seal were these elites who were collaborators with the colonial government and the missionaries. Of course, the situation was not so different from what was obtainable in the old practice where, according to Delano in the opening of the book, the elites and noble class were the ones controlling the affairs of state, with the king only making pronouncements.

19 Ibid., 41. 
The difference here is that the new elites had displaced the old ones, and while the old ones were working for their stomach and influence, the new ones had more to work for in addition to these considerations. The more to their quest was that they were working for the replication of Western civilization in the society. Going by this, they worked closely with the colonial government and the missionaries. Adegboyega Edun, one of the ex-slaves who was an educated Christian, became the first secretary of the modern Egba government. Like others after him, he wielded enormous influence in the government, so much so that he was considered to have been responsible for several uprisings in Abeokuta due to the government's policies. It was under the same criteria of Christianity and Western education that Edun got the job, and that others after him were appointed. This shows how powerful the Christian religion was in the society at this time, and how important it was for the people to think of jumping ship. As against the past when everything revolved round the Ogboni institution whose members were the police, the accuser, the judge, the kingmaker, the traditional doctor, the warrior and many more, this time, things changed..$^{20}$ The colonial government decided who became king, who was charged, and who would preside over a case. It had built hospitals with modern facilities and doctors. Through the missionaries, it had rendered redundant the traditional religious practices to the periphery so much so that anyone missing in a community became the problem of the warlords in the vicinity. The Ogboni cult had been rendered useless, and Delano thinks it was a sign of progress for the society, for how would someone come back from studying and still believe in these practices and injustices perpetrated by the group? ${ }^{21}$ Under the prevailing political atmosphere, even a king that missteps would dance to the European judicial tango.

\section{Delano and Literary Imaginations}

By the time traditions met modernization in Nigeria through colonization and colonial configurations, change and continuity in the ways of life of the people became a multifaceted long process that dictates the mood of the society far into the post-colonial period. Putting his literary fecundity into action, Delano provided us with intellectual expositions into this effect in mild but powerful narrations. This he was able to achieve, stylishly, primarily through the characters in his major literary works: L'OO'jọ Ojộ Un and Aiyé D'Aiyé Òinbó. In doing this, one could see and relate with Delano the historian, who bored the uninterested reader of historical works with historical details, particularly in L'OÓ jọ́ Ojọ Un. Yet, in the same analyses the boredom

20 Ibid., 123.

21 Ibid.,153. 
is decreased as one encounters Delano the literary icon putting comic reliefs into action, side-by-side with other poetic license, to pass the message of traditions and transformations in colonial Nigeria. By the time the historically indifferent folk finished reading Delano's literary works, they are likely, on the one hand, to be equipped with some sense of history and historical evolution of Nigeria without having to be trapped in the historian's intricate entanglements. On the other hand, they are most likely to have succeeded in fertilizing their cultural consciousness. It is invariably through these texts that Delano was established as a literary icon and the power of his literary aura could be successfully accessed. It suffices to mention here quickly-before the stature of this great writer is diminished-that the central focus of Delano all through his works was on cultural revival, i.e. Yoruba cultural vitality.

In achieving this aim, he never focused on one area of intellectual production. His engagements in this struggle transcended literary production to areas like language, biography, historical accounts and lot more. So, in counting his impact in the arena of cultural vitality through intellectual productions, this goes past the two literary productions for brief discussion here. Regarding the whole of his intellectual contributions to understanding culture, particularly that of the Yoruba, one thing is readily clear: the interconnectivity of the themes, setting and purpose of these works. Further signaling his historical and cultural mindfulness, these connections could also be seen in his other works outside literary productions. The only exceptions to this are his works on language. Interestingly, Delano still managed to bring his language productions within this context, not only as used for his expressions, but almost exclusively towards the last chapter of L'Ớ jọ Ojọ Un. In a creative manner, Fifake, the major character in the work, had brought the attention of her parents who showed no interest, to the kind of lessons taught by the village teachers. This later became a subject of interesting discussion between herself and her husband, Bamigbola. In narrating her experience with these teachers with her husband, through Fifake Delano went a long way to teach his readers about some common dynamics in the study of Yoruba as a language and the usage of òwe (proverbs), itàn (stories), àlọ (riddles), oríki (eulogies), and others. In a careful manner that blends with the story, it was related to us that:

Ede apejuwe ni ede Yoruba. A ma juwe nigbagbogbo. Bi ohun ba le bi okuta, Yoruba a ni ole. Bi Yoruba wa ni alafia, a ni 'ara mi le'; bi Oluko kan roro, ani 'Oluko na le'; bi omo kan ban se aigboran ati andola, ani 'omo na le'... ${ }^{22}$

22 Isaac O. Delano, L'Ọ́ jọ́ Ojộ́ Un. London: Thomas Nelson and Sons Ltd., p.130 
Yoruba language is descriptive. It describes at all times. If something is as hard as stone, Yoruba would refer to it as hard. If Yoruba is healthy, s/he would say my body is strong (never mind the euphemistic form of this in English); if a teacher is wicked, s/he would say the teacher is "hard"; if a child is stubborn, s/he would say the child is "hard"...

In the face of the present confused and porous Nigerian educational system, Delano waded-in in a tactical manner, as the discussion here went through the proper nature of education meant to be passed to pupils. We are informed that education for elementary school should be aimed to achieve three things: firstly, to know about themselves, the society, as well as their cultures and traditions. ${ }^{23}$ How many university graduates are aware of this in contemporary Nigeria, much less pupils and students in elementary schools? Here, we see Delano advocating for educational reform through his literary shrewdness. Another thing is that one could rarely have a clue that these works are actually literary productions from their titles. A quick glance conclusion supposes their historical content in the conventional manner. This way, one is tempted to expect an encounter with the documentation of cultures and peoples of Yorubaland in the familiar language of presentation. Again, one could impatiently ignore one of the two as a reproduction of the other as in the case of his The Singing Minister of Nigeria: The Life of The Rev. Canon J. J. Ransome-Kuti and Josaiah Ransome-Kuti: The Drummer Boy who became a Canon. But one could be fairly forgiven for this considering that both were produced within the same mind, context and relative content. Delano would not leave anyone in doubt of where he was coming from, so the historical consciousness that gave birth to this was declared when he wrote in the preface to L'Ớ jọ́ Ojọ Un that:

Olọgbọn ènià a má dáṣẹ dúró ní igbésí aiyé re, bóyá l'ọjộ ibí rẹ lọdọún, bóyá ní İbẹrẹ Odún titun tàbí lásikò iyípadà pàtàkì ní igbésí aiyé rẹ...Á dúró si, á dá wà nikan, á rántí ișẹgun rẹ; á ránití àárẹ, á ránttí ebi...; á rántí onírúurú nǹkan. İrántí yií á gbé àwòrán odúnmọdún kalẹ síwájú ojú ọkàn rẹ; bi ó bá jẹa alápọn yio kó ohun pàtàkì kíun silẹe bi ó bá jẹ olóòrayè yío fẹ kó gbogbo rẹ, bi ó bá jẹ aláida ki yío fẹ rántí ohun púpọ... Lásikò pàtàki tí orílẹèdè Nigeria di òminira yiú, ó ye kí á bójúwo èyin rántí onírúurú ohun to șelè ní ilú wa ní sáa kan. Ó yẹ kí á rántí ohun tí a rírí tàbí gbọ rí; kí á rántí kí á kọ ọ silẹ áti rán ẹlòmíràn l'étí láti rán gbogbo wa l'étí... ${ }^{24}$

23 Ibid., 36.

24 Ibid., v. 
A wise person would always make time to take a break from work in his life; on his yearly birthday, the New Year, or at certain times of some changes in his life...He would take a moment to recount, he would take to be alone, reflecting on all his successes, sicknesses, hunger,... and recounted a lot of things. The memory would give him the pictures of many years of struggles and accomplishments, if he is meticulous, he would take note of the important events, but if carefree, he would not budge, if he is a bad fellow, he wouldn't even want to remember many things... At this important moment when our country, Nigeria became independent, we must reflect on the events of the past, we must recollect on things we'd seen or heard, we must remember to write them down for others and as a reminder to ourselves.

Then, he went further with the historical truth that:

Bí ohun kan șojú ọpọlopọ èniàn léyin ìgbà pípẹ ọtọọtọ ni ohun tí wọn ó rántí nípa rẹ. Òtitọ ni gbogbo wọn ń sọ, ohun tí olúkúlùkù rántí ló yàtọ...Ohun tí ó bá kan olúkúlùkù l'ára ni yió rántí, bóyá on ni ó ṣe pàtàki fún un jùlọ. ${ }^{25}$

Though many people witnessed a certain event at the same time, they will remember different aspects of the event differently after a space of time. They report the facts based on the different aspect remembered about the events...individual of them will remember more about the aspect of the event that concerns him or her the most as these are the most important things to them.

It was all these that were drafted into this piece and the other, Aiyé D'Aiyé Oyinbó; both of which were presented as fictional and non-fictional concoctions. Take for instance, aside from the obvious ones-as in the issue of alcohol narrated in L'Ớ jọ Ojọ́ Un-the case of the Baale Ojusango in Aiyé D'Aiyé Oyinbó, who landed into trouble for administering justice in his community, was a non-fictional account presented in a fictional manner. Hence, Delano could not be regarded as a fiction writer, but a man that brought realities into fictional modes to liberalize issues discussed. These two books are therefore factional and not fictional. The moral of Delano's approach is that: the effective way of teaching is the informal technique. ${ }^{26}$ What is more, in a careful study of these works and the life of Delano, one could see a reflection of his

25 Ibid.

26 In Yoruba Home Life, one of his drafts, he illustrated how this type of learning helped in shaping the mind and educating the children before western education; a kind of education made impactful with less seriousness. 
personal experience and convictions weighing on the narrations. ${ }^{27}$ The theme of child mortality, rituals and traditions, parentage, colonization, urbanization, Christianity and Western civilization were in no doubt presented from his personal encounters, and it is possible the presentation of these themes could have taken another shape had it been he had a different backgroundfamily, work and life in general. Further laying credence to this is the personalization of the narratives in these two works with the use of the first-person singular, which could make one who had jumped the preface to wonder the "literary surgery" that transmuted Delano to a female at this time.

Deploying the power of the trinity; this time not in the biblical sense but related, one could capture the whole essence of Delano as a Cultural Evangelist, Christian Evangelist and Evangelist of Western civilization. Bringing the first into light, Delano was widely defined as one of the very few that pioneered writing in Yoruba after the language was reduced into writing by the missionaries. In this manner, he made history by helping to document literature that could help others to learn the language in written and spoken forms through these works. Going into this was the use of expressions, particularly in proverbs, wise sayings, taunting and non-verbal communication, that makes one aware of the power of the four significant tools in Yoruba communication methods. This was used in a fascinating manner all through the two books. The adoption of these tools is significant all through the works, but to have a clue of the effectiveness of these media, the instance of Balogun Igbein and Baale Babalola would suffice here for discussion. In the case of the former, he had gone to meet an indigenous pastor for clarity on some issues about becoming a Christian, particularly in regard to divorcing his wives to avoid polygamy. This indigenous pastor had replied that: $O$ tì. $N$ kò rò bẹe (No. I don't think so). Balogun smiled contemptuously. Knowing the background of the pastor as a product of a polygamous family, he replied: Yó tì. Kò șe ní tì. Eni tí baba ibá kọ ni yío pọ! (It must be false. Why won’t it be false. Those to be disowned by their fathers would have been many!) In this particular case, the pastor, being a native, understood what the Balogun was up to, but out of respect he failed to respond to the old man.

In some other cases, as in the case of Baale Ojusango and the Ajele Agba (the district officer), this could only be understood by an initiate present at the event. Taunting the ignorant white man after he failed him (Babalola) during

27 In a lecture delivered on him, Akinwunmi Isola only saw this from his convictions but ignored the personal experience of the author, ostensibly due to the scope of his engagement with the man. See Isola, "Making Culture Memorable: The Literary Contributions ff Isaac Oluwole Delano". [The essay is reproduced as Appendix 1.1 in Toyin Falọla. Cultural Modernity in a Colonized World: The Writings of Chief Isaac Oluwole Delano. Austin: Pan-African University Press, 2020.] 
his second travail in the hands of the colonial government, the Baale had replied to the admonition of the man for him to continue in his acts (i.e. his good acts that saved him in the case) by telling him to continue in his acts as well. This way, Babalola was telling the white man the power of karma. But it doesn't seem the poor white man understood, as he took the response literarily; he doesn't necessarily have to understand, that's one of the essences of taunting in Yorubaland. Aware of the power of language usage, a reader could learn through these two cases, among many others, the power of rhetoric often engaged in some peculiar cases to pass distinctive messages in the Yoruba language. Similar to this is the non-verbal communication which is also esoteric: ó fi ojú gbé e (he derided him/her with his eyes). This was also used by the Baale against the District Officer, in protest of his frustration by the colonial government and reaction to his (the District Officer) attitude towards him in a meeting. Again, in this narration, Asabi told us that the white man could not relate with this significant communication skill used by parents to caution their children and women to fight one another. ${ }^{28}$

In an equally effective manner, Delano deployed the power of proverb, which is in all cases embedded with wise sayings in a succinct manner, summarizing what a speaker intends to say. Is it not true that the tree that one decides to rest on but falls, cannot kill the fellow if it chose to fall on him/ her? Or how early can a child get to the farm to greet the spirits residing in the farm, welcome? All these and many more are Yoruba succinct wise sayings that confound the non-initiate, thereby giving credence to the richness of the language, as its traditions and culture. Although he later went on to produce a separate book on Yoruba proverbs, just as he did on Yoruba language usage which also featured in $L^{\prime} O^{\prime}$ jọ $O j o ̣$ Un as earlier noted, their adoption in these literary works adumbrate their usages with interesting construction. In-between all of these were critiques of the Yoruba cultural values presented vis-a-vis family structure, societal expectations, marriage traditions, political morphology and lot more. Balogun Igbein showed how constructive and succinct proverbs could be used in relaying one's intent in a particular situation. Depending on the magnitude of the matter at hand, this means they could be engaged using different interlocking proverbs which on their own could be used differently to express different situations. In this particular instance, the Balogun, answering questions from the Ogboni, the most powerful traditional political composition in Egbaland, retorted to a challenge posed to him that: ogbọ́n ọlọgbọ́n ki i jẹ kí a pe àgbà ní wèrè. Eni tí ó fi ọràn ẹlòmíràn kọgbộn

28 Chief Isaac O. Delano, Aiyé D’Aiyé Òyinbó, London: Thomas Nelson and Sons Ltd., 1970. 
l'olórí eni tí ó gbọn. Bí e ò ríran, e ò rí bàibài. ${ }^{29}$ In these three proverbs laid the whole context of what the Balogun intended to tell the ògbóni.

Aside from proverbs, the use of short sayings with poetic power that register the message of the messenger to the receiver informed us about another dimension in how the Yoruba communicate their intention without having to say much, in some cases. Here we get something like:

Ikú Ogun ní ípa akíkonjú,

Ikú odò ní ípa òmùwẹ;

Ikú ẹwà ní ípa ọkín,

Ikú ara ríre ní ípa oge. ${ }^{30}$

The death of a warrior lies in the battles

The death of a swimmer lies at the sea

The death of a peacock lies in its beauty

The death of the elegant one lies in her beauty.

This is a cautionary tale structured in a poetic form to address the excesses of anyone in view. Essentially, all these succinct wise sayings deployed in Delano's works, especially in L'O'jọ́ Ojọ Un, that uniquely mesmerize his readers and induce their curiosity of the Yoruba civilization, are living texts orally passed down to generations in Yorubaland to be strategically invoked whenever needed. ${ }^{31}$ Paradoxically, perhaps, all through the two literary works, Delano never hid his affection for Christianity, gratitude to the European agents of civilization, the missionaries and the colonial government, and disdain for some cultural practices. Like other serious issues discussed in his works, which in other academic discourses are matters of intense debate with nerve-racking references, these were taken lightly. Further portending his ability to soften the ground for his readers, the use of diagrams that depict the author's illustrations in these books creates a captivating atmospheric condition in the imagination of his readers. As such, to visualize the literary prowess of Delano is to think of a man whose fictions are found in reality; and his truth, in the sense of time and space in which he lived. As Professor Akinwunmi Isola rightly observed, Delano was a proud promoter of the Egba culture. ${ }^{32} \mathrm{He}$ was evidently not apologetic about this, as in the positions he took on other issues. This way, the setting of the two texts was created in Abeo-

29 Delano, L’ớ jọ́ Ojộ́ Un, 117.

30 Ibid., 120.

31 Cf. Karin Barber, The Anthropology of Texts, Persons and Publics: Oral and written culture in Africa and Beyond. Cambridge: Cambridge University Press, 2007.

32 Isola, "Making Culture Memorable," 8. 
kuta with inferences to events among the people. In the final analysis, owing to his approach to literary production, Delano's works serve as viable sources of information for historical events in Nigeria.

\section{Delano on Men, Power, and History}

Whether one chooses to concentrate his/her searchlight on Africa or elsewhere in the world, one thing is apparent in the composition of human civilizations, and that is the domineering nature of men. It has once been said that history is the account of great men. Even though this nature of historical account has since been deconstructed by attempts to listen and document the stories of the underdogs, with the view of understanding historical events from the views of the ordinary people, the masculinity of these accounts are often conspicuous. In many cases, this is not a conscious attempt by the historian or the chronicler to go down this path, but rather just the way the society has been constructed over the ages. To go the other way round, i.e., to concentrate on the role of women in history, is to stir the consciousness of the writer which breaths more life into the question of keen conscious subjectivity. In most cases, these studies have shown the tendency to remove every other element in the society to focus on the women, with the consequence of painting the picture of a victim in an isolated society; they call this "gender equality". However, while Delano never delved into this debate in his works, one could see through his concept of history, man and society as an interlocking space of hierarchy, the concepts of role-play and cooperation.

It is true that men take the center-stage of historical discourse, even when such discourse takes the form of a literary bearing. In Delano's Aiyé D’Aiyé Òinbó or L'O'jộ Ojọ́ Un, it is readily revealing to any discerning mind without a mischievous intent that the men at the center-stage of historical events would have been nothing of historical significance-either as villains or heroes-without a woman. ${ }^{33}$ In Aiyé D’Aiyé Òyinbó, for instance, Baale Babalola was able to successfully climb the herculean hills placed in front of him by the colonial incursion through the love, support and guidance of his wife. Both in Aiyé D’Aiyé Òyinbó and L'O'jọ Ojọ̣ Un, Delano provided us with sundry instances of how men attain their historical status through the agency of women. In this way, men are seen as the embodiment of the "Wo" and the "Men." A man without a wife is considered impotent and insignificant; likewise, the same goes for a woman without a man. Because of the front position they occupy in the home as well as the entire society, men are revered both by

33 Cf. Isaac 0. Delano, The Singing Minister of Nigeria: The Life of the Rev. Canon J. J. Ransome-Kuti: London, United Society for Christian Literature and Lutterworth Press, 1945. 
women and children. Delano observed that as husbands, whose primary purpose is to provide for their home, they maintain a tight schedule that tends to remove them from the home compared to the mothers. This way, the mothers become closer to the home front seeing to events on their behalf, while the fathers go out to ensure that proper meals are put on the table in the evening and at all times. Although women, particularly in the Yoruba tradition, are not restricted to the home, they engage in economic activities that take them away from home as well to support the family; this is done to the extent of the understanding between them and their husbands. As the man gets married, the wife, as seen in the case of Babalola, becomes his mother, while he in turn becomes the father of the woman. The manner in which the man treats his wife now depends on his proclivity.

While some husbands are domineering, others are subtle. But in either case, they are responsible for discharging punishments in the home or giving verdict on matters. In his analyses of the Yoruba home life, Delano observed that even when a child had done something wrong during the day with the awareness of his/her mother, the mother would wait till the father comes back in the evening to report such a child. The child would not be surprised because he/she would have been initially told about this by the mother; and even when the mother did not say a thing, the child would be already familiar with the trend. He/she could only wait till evening to hear the sound of the music to dance to. As the fear of God is the beginning of wisdom in the fundamental Christian doctrine, the fear of the father is at the root of the African family doctrine. As a patriarchal society, every man is a king in his own right. In his home, as briefly mentioned above, he performed the same function an $o b a$ is saddled with at the community level. The prosperity, discipline and general nature of the home revolve around him and his decisions. Yet, like the king of the community, these decisions are seldom taken without the knowledge of the wife. This is more so when such decisions concern the whole family. Life in Yorubaland, like in every other part of Africa, is divided into three different stages; and these stages are considered the most crucial in the life of every man and woman: birth, marriage and death are periods of essential transitions.

In none of these three stages could a man cross without a woman. When, for instance, Balogun in Aiyé D'Aiyé Òyinbó and Balogun Igbein in L'Ọ́ jọ́ Ojjọ́ Un wanted to give their daughters out for marriage, although it was the position of the two men that prevailed, the tactical support of their wives made their efforts successful. In the former case, the mother couldn't understand why the Balogun was so bent on the choice of Babalola, but this was only because of the manner in which the Balogun went about it and not because of the generic proclivity of men. The Balogun, for reasons not stated in the 
novel, other than his love for his daughter, had gone to a fortune teller to inquire about the future of his daughter, Asabi, without the knowledge of the mother. It was based on the fortune teller's findings that he was acting without the knowledge of anyone aside from himself and fortune teller. Considering the honor and confidence a wife is expected to repose in her husband, the wife-seeing the confidence with which the Balogun was pursuing this conviction - had to support him before getting to know the reason behind his actions. It turned out well and, with the intervention of the mother, what could have been a family disaster-because Asabi already had a date she was equally determined to marry-was abated with the diplomatic fecundity of the woman. In the other two stages, the question that resonates in all of Delano's works, including his biographical accounts, is: Given the importance attributed to children, how would a man reproduce himself without a woman and, when he reproduces, who would ensure that his home front, which includes the children, is well managed when he's away?

Nonetheless, in their domineering nature, Delano showed that a good kid is the child of the father, while the bad ones belong to the mother; the reason being that the mother spends more time with the children and whatever attitude picked up by the child is concluded to be from the prodding of the mother. In any case, while the man controls the home and the community with force, subtleness is the instrument of the woman. The latter, in most cases, has been proven to be more effective from the Garden of Eden. Therefore, why men are at the helm of the society at center-stage, women are the directors backstage. All through the historically insightful literary pieces of Delano, this truth is made evident. In fact, in Aiyé D’Aiyé Òyinbó, one is not oblivious to the reality that Asabi was the one in-charge of the affairs of Ojusango; Baale Babalola was only making the command. This is the case in every home; the difference is in the status of the woman doing the remote-control: she could be the wife or the concubine. Going through his personal life, what one gets is the picture of the overwhelming influence of women in the life of a man. In the final analysis, from the historical background annexed by Delano, neither the man nor the woman is helpless in their relationship; the innate inclination of the individual in view determines their relationship. Since the spectators in most cases are expected to see what the director wants them to see, what they see is the role of men in shaping history and the society. This is not to deny the reality of male chauvinism, but implicitly taken from Delano, this is also a function of the recycled common fiction around which the society evolves. Women themselves are not at loss of their unique influence.

Agreeably, the hierarchical nature of the society makes possible the functions and limitations of members of the society. This makes for continuity and stability. Meanwhile, these actions are intertwined. Aside from the innate 
feature of the individual, we are reminded through Delano's works that history, man, power and their actions are abstract forms and yet, concrete in the common myth we have chosen to believe. Hence, a wife is not only expected to revere her husband-considered to be the king of his family; the honor must be extended to the family of the man in a fearful manner. On his part, the man is expected to also honor his in-laws. The reason for this is best explained in the social functional purpose of marriage in Africa: the woman is married to the family of the husband and vice versa. It doesn't matter the extent of power wielded by the man; the moment he gets engaged with a woman, the in-laws become part of his "gods."

\section{Delano and His Non-Writing Projects}

Since the in-depth liberalization of the Nigerian political space by the Lyttleton Constitution, which built on the Richard's Constitution in 1954, various indigenous political clusters have evolved into several stages, reflecting in their names; organization; structure; and the like. In most cases, however, these parties maintained their central ideology, although some alterations might be made to reflect the reality of different arms of this ideology as shown by their lifespan. Owing to the preponderance of cultural affinity in the mobilization of support by these political parties, many of them emerged from cultural groups. It is in this respect that the Action Group (AG) germinated into a big political tree in the political forest of the Western Region from the seed of the Egbe Omo Oduduwa in 1951. ${ }^{34}$ Until his demise in 1979, Chief Delano was among the steadfast loyalists of the party. As a man who was well-grounded in the idea of cultural revival-a notion that resonates with Africanity-it is not surprising to note that he pursued this ideology through every noble available means at the time. Before the inception of modern political structure brought about by the agents of modernization in the area known today as Nigeria, the all-encompassing dominance of politics in all spheres of the society was never lost on Delano. Inter alia, his background as a son of a Balogun is telling in this exposure.

As such, when the Egbe Omo Oduduwa was established in 1945, Delano through his efforts and dedication became the first administrative secretary of the organization in the Western Region. It was in this capacity that he superintended over the mobilization process and other itineraries of the organization upon which the Action Group became known. Aside from the cultural affinity he shared with the organization and its political party branch,

34 Cf. Insa Nolte, Obafemi Awolowo and the Making of Remo: The Local Politics of a Nigerian Nationalist. London: Edinburgh University Press for the International African Institute, 2009. 
it is revealed in records that they shared the same ideology. The party's policy on education, trade, commerce and industrialization, for instance, were driven by the twin forces of nationalization and localization of productions, which the party referred to as the "Nigerianisation policy." Thus, convinced of the core place of education in achieving this agenda, the Western Region government-controlled by the party-saw to the implementation of its free education policy. Be that as it may, the scheme was not just to prepare pupils and students for white collar jobs; they were equally prepared for the blue-collar ones. As such, lessons in crafts were encouraged, thereby giving room for an adequate relationship between the town and the gown. This, the party described in terms of industrialization and the expansion of educational institutions. Alongside this was the promotion of the cultural and civic orientation of the students. On industrialization and commerce, the party sought to annex all local possibilities that could spring the region into a formidable force in the country and, indeed, the entire African continent.

This way, it made efforts to promote native talents and native inventiveness in exploring, for instance, its forests for viable contents in furniture making, plants with medicinal values, and many others; as in the possibility of commercializing local gin and producing bottled palm wine. As if all these were not enough to paint the picture of what Delano stood for through the professed ideology of the organization, the Action Group believed that though it needed to go on this path, it would not hesitate to welcome foreign investors and partnerships insofar as the local interests were protected. Hence, it "would want a controlling share held either directly by the Government, its agents or Nigerians."

While the government was pursuing this agenda with the support of the likes of Chief Delano, until it became a victim of the venomous politics of the time, Fafunwa and others including the Chief were organizing meetings where they mulled over the idea of promoting indigenous language as a medium of instruction and learning in schools, this time in the Western Region. Their position was based on the UNESCO's findings that children learn better when they are instructed in classes by their indigenous language. The apparent problem with the adoption of this method of teaching is the cultural complexity of Nigeria. Anyway, the project which was supposed to focus on primary school pupils was tagged the "Ife Six-Year Primary Project" Expectedly, the adoption of an indigenous language, Yoruba in this case, for the purpose of teaching all subjects-including mathematics and other science-related subjects-was meant to be daunting. However, with the vast spread of indigenous scholars in each of the fields covered by these subjects, the challenge of finding adequately equipped personnel to produce the needed books, training of teachers and other technicalities, did not suffice. Among these 
experts was Delano, who was at the time a colossus in the Nigerian society of linguists and literary writers. In achieving its goals, the project coordinators shrewdly observed that adequate monolingual dictionaries would be needed for quick checks of relevant words to be used in teaching and learning these subjects. Interestingly, long before the commencement of this project, Delano had produced books similar to this, among which was one entitled Atúmọ Èdè Yorùbá, which was of particular interest to the project committee. This, along with his other works like A Dictionary of the Yoruba Monosyllabic Verbs, Conversation in Yoruba and English, Aiyé D’Aiyé Òyinbó, and many more, made Delano's presence on the project's Board of Executives insightful.

It goes without mentioning that the purpose of this project and the agenda of the Western Region government under the AG were very much similar. Although the Action Group did not advocate for the adoption of Yoruba as the language of instruction in schools in the region, its vision of what education should look like and its impact on the society, as briefly mentioned above, was in sync with that of the project organizers. Curricula were designed to include vocational aptitudes in which the schools were to partner with worthy artisans in the society, whose workshops would be visited periodically by pupils for practical knowledge of what they might have been thought in class by their teachers, and on some occasions, by the artisans themselves. It is instructive to note that the wisdom of this idea is not lost on current scholars with clear thoughts on the development agenda of the Nigerian state. ${ }^{35}$ To achieve maximum success of the program, the organizers agreed that the central posture of the pedagogy of teaching should be education through fascination, i.e. liberalizing knowledge so as to make learning in the Yoruba language appealing to the children. Therefore, they encouraged the use of images, colors and others, for illustrations in books. Meanwhile, Delano had long been using this medium, particularly the former, in his books. In the final analysis, this was another platform for him to continue to advocate for what he believed in.

Further in this regard, as one of the pioneer linguists in Nigeria and indeed the West African region, Delano attended several meetings, conferences and congresses of the West African Linguistic Society where issues on phonetics, phonology, morphology, syntax, typology and history of West African languages and the like were discussed. As he was doing this, he was also engaged with the West African School Certificate Examination in various capacities: as an Examiner in Yoruba at the Ordinary Level, Chief Examiner and Chief Supervisor/Coordinator. In these capacities, Delano continued his advocacy for

35 See for instance, the same picture as mirrored on Toyin Falola, "Technology, Culture and Society," 1st Distinguished Annual Lecture First Technical University, Ibadan, July 4, 2019. 
the revitalization of the Yoruba language. The passion with which he pursued this goal would not allow him to compromise on the required professional conduct to drive the message home. Hence, in examining scripts, Delano would return examiners to their scripts, not to upgrade marks-as this was never found in the records-but to degrade candidates he felt had not done accurately enough to merit the score accredited to them in the first place. This makes him sound paternalistic and rigid in most cases. For instance, in his correspondence with one Mr. Popoola at Anglican Grammar School, Gbongan, Delano had told the examiner to deduct 2 marks from the scores of candidates who failed to write the title of the essay they'd written, and 1 mark from those who failed to do this properly.

Giving an instance of the intricacy of studying Yoruba as a language, Delano reminded his examiners that they should note that though a male in Yoruba is referred to as $a k o$ and a female $a b o$, one cannot ask in the instance of getting to know the gender of a visitor: $a k o-n$-bábo? This is only used to inquire about the gender of a new-born baby. Nonetheless, going through his records in this area, one could at the same time see through a liberal Delano who admonished his team of examiners to be wary of scoring candidates strictly based on the specimen answers given to them for marking scripts, considering that this could be very difficult and put smart candidates at disadvantage. This way, what they should be looking for in grading should be the extent of the relevance of answers provided by each candidate in relation to the specimen answer. This position places Delano not only in the realm of constructivist educators per excellence, but as a progressive critical thinker.

Altogether, Delano, in his activities, in and outside of writing and publishing, continued to address the issue of culture, modernity, and cultural revival for the development of the society. Having presented a panoramic view of the ideas that governed the intellectual world of Delano through a careful study of his various works, as represented here, in the next chapter, I shall focus on connecting these dots to a larger body of ideas framed within relevant theoretical prisms of modernization. It is in this light that the global paradigm of this volume shall be given a solid foundational touch. 